\title{
Impact of intracellular toxic advanced glycation end-products (TAGE) on murine myoblast cell death
}

\author{
Takanobu Takata*, Akiko Sakasai-Sakai and Masayoshi Takeuchi
}

\begin{abstract}
Background: Sarcopenia is a progressive condition that is characterized by decreases in skeletal muscle mass and function. Although sarcopenia is associated with lifestyle-related diseases (LSRD), the mechanisms underlying cell death in myoblasts, which differentiate to myotubes, remain unclear. We previously designated glyceraldehyde (an intermediate of glucose/fructose metabolism)-derived advanced glycation end-products (AGEs) as toxic AGEs (TAGE) because of their cytotoxicity and involvement in LSRD, and hypothesized that TAGE contribute to cell death in myoblasts.

Methods: C2C12 cells, which are murine myoblasts, were treated with 0, 0.5, 1, 1.5, and $2 \mathrm{mM}$ glyceraldehyde for $24 \mathrm{~h}$. Cell viability and intracellular TAGE were then assessed using 5-[2,4,-bis(sodioxysulfonyl)phenyl]-3-(2-methoxy4-nitrophenyl)-2-(4-nitrophenyl)-2H-tetrazole-3-ium (WST-8) and slot blot assays. Cells were pretreated with $8 \mathrm{mM}$ aminoguanidine, an inhibitor of AGE production, for $2 \mathrm{~h}$, followed by $0,1.5$, and $2 \mathrm{mM}$ glyceraldehyde for $24 \mathrm{~h}$. Cell viability and intracellular TAGE levels were then assessed. Serum TAGE levels in STAM mice, in which there were four stages (no steatosis, simple steatosis, steatohepatitis, and fibrosis), were measured using a competitive enzyme-linked immunosorbent assay. Results were expressed as TAGE units (U) per milliliter of serum, with $1 \mathrm{U}$ corresponding to $1.0 \mathrm{\mu g}$ of glyceraldehyde-derived AGE-bovine serum albumin (BSA) (TAGE-BSA). The viability of cells treated with 20, 50, and $100 \mu \mathrm{g} / \mathrm{mL}$ non-glycated BSA and TAGE-BSA for $24 \mathrm{~h}$ was assessed using the WST-8 assay.

Results: In C2C12 cells treated with 1.5 and $2 \mathrm{mM}$ glyceraldehyde, cell viability decreased to $47.7 \%(p=0.0021)$ and $5.0 \%(p=0.0001)$ and intracellular TAGE levels increased to 6.0 and $15.9 \mu \mathrm{g} / \mathrm{mg}$ protein, respectively. Changes in cell viability and TAGE production were completely inhibited by $8 \mathrm{mM}$ aminoguanidine. Serum TAGE levels at the steatohepatitis and fibrosis stages were $10.51 \pm 1.16$ and $10.44 \pm 0.95 \mathrm{U} / \mathrm{mL}$, respectively, and were higher than those at the no steatosis stage $(7.27 \pm 0.18 \mathrm{U} / \mathrm{mL})$. Cell death was not induced by 20 or $50 \mu \mathrm{g} / \mathrm{mL}$ TAGE-BSA. The viabilities of C2C12 cells treated with $100 \mu \mathrm{g} / \mathrm{mL}$ non-glycated BSA and TAGE-BSA were $105.0 \%(p=0.2890)$ and $85.3 \%$ $(p=0.0217)$, respectively.
\end{abstract}

Conclusion: Intracellular TAGE strongly induced cell death in C2C12 cells and may also induce myoblast cell death in LSRD model mice.

Keywords: Sarcopenia, Lifestyle-related diseases, Myoblasts, Advanced glycation end-products, Glyceraldehyde, Toxic advanced glycation end-products, C2C12 cells

*Correspondence: takajjjj@kanazawa-med.ac.jp

Department of Advanced Medicine, Medical Research Institute, Kanazawa

Medical University, Uchinada-machi, Ishikawa 920-0293, Japan

\section{Background}

Skeletal muscle requires exercise, the synthesis of glycogen, and interactions with other organs, such as the liver and adipose tissue [1]. Sarcopenia is a progressive

(c) The Author(s) 2020. This article is licensed under a Creative Commons Attribution 4.0 International License, which permits use, sharing, adaptation, distribution and reproduction in any medium or format, as long as you give appropriate credit to the original author(s) and the source, provide a link to the Creative Commons licence, and indicate if changes were made. The images or other third party material in this article are included in the article's Creative Commons licence, unless indicated otherwise in a credit line to the material. If material is not included in the article's Creative Commons licence and your intended use is not permitted by statutory regulation or exceeds the permitted use, you will need to obtain permission directly from the copyright holder. To view a copy of this licence, visit http://creativeco mmons.org/licenses/by/4.0/. The Creative Commons Public Domain Dedication waiver (http://creativecommons.org/publicdomain/ zero/1.0/) applies to the data made available in this article, unless otherwise stated in a credit line to the data. 
condition that is characterized by decreases in skeletal muscle mass and function, resulting in the deterioration of activities of daily living and quality of life as well as increases in the risk of falls and mortality [2]. Skeletal muscle consists of myotubes that differentiate from myoblasts; therefore, one of the mechanisms contributing to the loss of skeletal muscle is the death of or dysfunctions in myoblasts [2-6]. Accumulating evidence has shown that lifestyle-related diseases (LSRD) such as type 2 diabetes mellitus (T2DM) and non-alcoholic steatohepatitis (NASH) has an increased risk of sarcopenia $[2,7,8]$. However, the mechanisms underlying cell death in myoblasts in LSRD model animals and patients with LSRD have not yet been elucidated. The relationships between cell death in myoblasts in vitro and risk factors for LSRD currently remain unclear. Mastrocola et al. previously reported that the levels of $N^{\varepsilon}$ carboxymethyllysine (CML) and $N^{\varepsilon}$-carboxyethyllysine (CEL)-modified proteins, which are advanced glycation end-products (AGEs), were elevated in the skeletal muscle of $\mathrm{C} 57 \mathrm{Bl} / 6 \mathrm{j}$ mice and ob/ob mice, which is an obese model mouse, and identified abnormalities in skeletal muscle (including the loss of skeletal muscle mass, myosteatosis, and oxidative stress) $[9,10]$. CML and CEL-modified proteins have been suggested to play a role in sarcopenia. Although the relationships between these AGEs and cell death in myoblasts remain unclear, based on the findings reported by Mastrocola et al. from skeletal muscle tissue, AGEs may be generated in myoblasts.

In the present study, we investigated whether glyceraldehyde (an intermediate of glucose/fructose metabolism)-derived AGEs were generated in $\mathrm{C} 2 \mathrm{C} 12$ cells, which are murine myoblasts. We focused on glyceraldehyde because we previously designated glyceraldehyde-derived AGEs as toxic AGEs (TAGE) based on their cytotoxicity and involvement in LSRD, such as T2DM, NASH, cardiovascular diseases (CVD), and cancer [11-15]. TAGE appear to be generated in myoblasts and induce cytotoxicity based on previous findings showing their production in neuroblastoma cells, hepatic cells, pancreatic cells, and cardiac cells as well as their induction of cell death and dysfunction [1622]. TAGE in the blood which are one of extracellular TAGE increase in patients with LSRD and induce cytotoxicity in cells via receptor for AGEs (RAGE) [11-13, 15, 23]. Extracellular TAGE which are generated in other cells and secreted or released into the blood may induce cytotoxicity in myoblasts because they express RAGE [2]. Therefore, we investigated the cytotoxicity of glyceraldehyde-derived AGE-bovine serum albumin (BSA) (TAGE-BSA), a model of extracellular TAGE, in C2C12 cells.

\section{Methods}

Reagents, cell lines, and serum of STAM mice

Dulbecco's modified Eagle's medium (DMEM) and penicillin-streptomycin solution were obtained from Sigma-Aldrich (MO, USA). Fetal bovine serum (FBS) was purchased from Bovogen-Biologicals (VIC, Australia). Glyceraldehyde was purchased from Nacalai Tesque Inc. (Kyoto, Japan). The 5-[2,4,-Bis(sodioxysulfonyl) phenyl]-3-(2-methoxy-4-nitrophenyl)-2-(4-nitrophenyl)$2 \mathrm{H}$-tetrazole-3-ium (WST-8) assay kit and 3-[(3-cholamido-propyl)-dimethyl-ammonio]-1-propane sulfonate) (CHAPS) were obtained from Dojindo Laboratories (Kumamoto, Japan). The ethylene diamine-N,N,N'N'tetraacetic acid (EDTA)-free protease inhibitor cocktail was obtained from Roche Applied Science (Penzberg, Germany). C2C12 cells were obtained from KAC Co., Ltd. (Kyoto, Japan). The serum of non-fasted STAM mice was purchased from SMC Laboratories, Inc. (Tokyo, Japan). The protein assay kit for the Bradford method was obtained from Takara Bio, Inc. (Otsu, Japan). A horseradish peroxidase (HRP)-linked molecular marker was obtained from Bionexus (CA, USA). A HRP-linked goat anti-rabbit IgG antibody was purchased from DAKO (Glostrup, Denmark). All other reagents and kits not indicated were purchased from Fujifilm Wako Pure Chemical Co. (Osaka, Japan). TAGE-BSA, non-glycated BSA, and an anti-TAGE antibody were prepared as described previously [24].

\section{Cell culture and cell seeds}

C2C12 cells were incubated in DMEM supplemented with $10 \%$ FBS, $100 \mathrm{U} / \mathrm{mL}$ penicillin, and $100 \mathrm{mg} / \mathrm{mL}$ streptomycin under standard cell culture conditions (humidified atmosphere, $5 \% \mathrm{CO}_{2}, 37{ }^{\circ} \mathrm{C}$ ). Cells were seeded $\left(1.9 \times 10^{4}\right.$ cells $\left./ \mathrm{cm}^{2}\right)$ on 96 -well microplates and culture dishes (Becton-Dickinson, NJ, USA).

\section{Glyceraldehyde and aminoguanidine treatments of C2C12 cells}

Glyceraldehyde was dissolved in phosphate-buffered saline (PBS) without $\mathrm{Ca}^{++}$and $\mathrm{Mg}^{++}((\mathrm{PBS})(-))$, and then filtered before being added to $\mathrm{C} 2 \mathrm{C} 12$ cells. The volume of PBS (-) (including glyceraldehyde) was 2.0 $\mu \mathrm{L} / 100 \mu \mathrm{L}$ of the total medium volume. All experiments were performed $24 \mathrm{~h}$ after treatments with $0,0.5,1,1.5$, and $2 \mathrm{mM}$ glyceraldehyde. The cell culture method before the treatment with aminoguanidine (the volume of PBS (-) (including aminoguanidine) was $2.0 \mu \mathrm{L} / 100 \mu \mathrm{L}$ of the total medium volume), an inhibitor of AGE production, was the same as that described above. Cells were pretreated with 0 or $8 \mathrm{mM}$ aminoguanidine for $2 \mathrm{~h}$ followed 
by $0,1.5$, and $2 \mathrm{mM}$ glyceraldehyde for $24 \mathrm{~h}$ (the volume of PBS(-) (including glyceraldehyde) was $2.0 \mu \mathrm{L} / 102 \mu \mathrm{L}$ of the total medium volume).

\section{Cell viability of $\mathrm{C} 2 \mathrm{C} 12$ cells treated with glyceraldehyde and aminoguanidine}

Cell viability was assessed using the WST-8 assay. Medium containing glyceraldehyde/aminoguanidine was removed and cells were washed with PBS $(-)$. Ten microliters of WST-8 reagent was added to 96-well microplates in which C2C12 cells were cultured in medium $(100 \mu \mathrm{L})$, and this was followed by an incubation at $37^{\circ} \mathrm{C}$ for $2 \mathrm{~h}$ in a $\mathrm{CO}_{2}$ incubator. Absorbance was measured at 450 and $655 \mathrm{~nm}$ using a microplate reader (Bio-Rad, CA, USA). Medium in the wells without cells was treated with glyceraldehyde/aminoguanidine, a medium change, and WST-8 reagent to measure background absorbance. Background absorbance was subtracted from experimental values.

\section{Assessment of intracellular TAGE in C2C12 cells treated with glyceraldehyde and aminoguanidine using a slot blot analysis}

This analysis was performed as described previously with some modifications [20-22]. Cells were washed with $(\mathrm{PBS})(-)$ and then lysed in buffer [a solution of $2 \mathrm{M}$ thiourea, $7 \mathrm{M}$ urea, 4\% CHAPS, and $30 \mathrm{mM}$ Tris, and a solution of EDTA-free protease inhibitor cocktail (9:1)]. Cell extracts were then incubated on ice for $20 \mathrm{~min}$, centrifuged at $10,000 \times g$ at $4{ }^{\circ} \mathrm{C}$ for $15 \mathrm{~min}$, and the supernatant was collected as the cell extract. Protein concentrations were measured using the protein assay kit for the Bradford method with BSA as a standard. Regarding the detection of TAGE, equal amounts of cell extracts, the HRP-linked molecular marker, and TAGE-BSA were loaded onto polyvinylidene difluoride (PVDF) membranes (0.45 $\mu \mathrm{m}$; Millipore, MA, USA) fixed in the slot blot apparatus (Bio-Rad). PVDF membranes were cut to prepare two membranes and then blocked at room temperature (r.t.) for $1 \mathrm{~h}$ using 5\% skimmed milk in PBS(-) containing $0.05 \%$ Tween 20 (skimmed milk-PBS-T). After this step, we used $0.5 \%$ of skimmed milk-PBS-T for washing or as the solvent of antibodies. After washing twice, membranes were incubated with (1) the anti-TAGE antibody (1:1000) or (2) neutralized anti-TAGE antibody (a mixture of the antiTAGE antibody (1:1000) and $250 \mu \mathrm{g} / \mathrm{mL}$ of TAGE-BSA) at $4{ }^{\circ} \mathrm{C}$ overnight. Membranes were then washed four times. Proteins on the membrane were incubated with the HRP-linked goat anti-rabbit IgG antibody (1:2000) at r.t. for $1 \mathrm{~h}$. After washing three times with PBS-T, membranes were moved into PBS(-). Immunoreactive proteins were detected with the ImmunoStar LD kit and band densities on the membranes were measured using the Fusion FX fluorescence imager (M\&S Instruments Inc., Osaka, Japan). The densities of HRP-linked molecular marker bands were used to correct for differences in densities between membranes. The amount of TAGE in cell extracts was calculated based on a calibration curve for TAGE-BSA.

\section{Analysis of serum TAGE levels in STAM mice}

TAGE levels in the serum of STAM mice were measured using a competitive enzyme-linked immunosorbent assay. The serum of mice, in which stages were no steatosis, simple steatosis, steatohepatitis, and fibrosis (four mice in each group) was analyzed. Briefly, each well of the 96-well microplate was coated with $1.0 \mu \mathrm{g} / \mathrm{mL}$ TAGEBSA and incubated overnight in a cold room. Wells were washed three times with $0.3 \mathrm{~mL}$ of PBS containing $0.05 \%$ Tween 20 (PBS-T). Wells were then blocked by an incubation for $1 \mathrm{~h}$ with $0.2 \mathrm{~mL}$ of a solution of PBS containing $1 \%$ BSA. After washing with PBS-T, test samples (50 $\mu \mathrm{L}$ ) were added to each well as a competitor for $50 \mu \mathrm{L}$ of the anti-TAGE antibody (1:1000), followed by an incubation at r.t. for $2 \mathrm{~h}$ with gentle shaking on a horizontal rotary shaker. Wells were then washed with PBS-T and developed with alkaline phosphatase-linked anti-rabbit IgG utilizing $p$-nitrophenyl phosphate as the colorimetric substrate. Results were expressed as TAGE units (U) per milliliter of serum, with $1 \mathrm{U}$ corresponding to $1.0 \mu \mathrm{g}$ of a TAGE-BSA standard as described previously [24]. Sensitivity and intra- and interassay coefficients of variation were $0.01 \mathrm{U} / \mathrm{mL}$ and 6.2 and $8.8 \%$, respectively [25].

\section{Non-glycated BSA and TAGE-BSA treatment of $\mathrm{C} 2 \mathrm{C} 12$ cells and assessment of cell viability}

C2C12 cells were treated with 0,2050 , and $100 \mu \mathrm{g} / \mathrm{mL}$ of non-glycated BSA and TAGE-BSA, and then incubated for $24 \mathrm{~h}$. Cell viability was measured using the WST-8 assay. The ratio of cell viability was calculated based on the viability of cells treated with TAGE-BSA versus those treated with non-glycated BSA.

\section{Statistical analysis}

Stat Flex (ver. 6) software (Artech Co., Ltd., Osaka, Japan) was used for statistical analyses. Data were expressed as mean \pm standard deviation (S.D.). When statistical analyses were performed on data, significant differences in the means of each group were assessed by a one-way analysis of variance (ANOVA). We then used the Bonferroni or Tukey's test for an analysis of variance. P-values $<0.05$ were considered to be significant. 


\section{Results}

Viability of $\mathrm{C} 2 \mathrm{C} 12$ cells treated with glyceraldehyde

The viability of $\mathrm{C} 2 \mathrm{C} 12$ cells treated with 0.5 and $1 \mathrm{mM}$ glyceraldehyde did not decrease, whereas dosedependent decreases to 47.7 and 5.0\% were observed in those treated with 1.5 and $2 \mathrm{mM}$ glyceraldehyde, respectively (Fig. 1a).

\section{Quantity of intracellular TAGE in C2C12 cells treated with glyceraldehyde}

Intracellular TAGE were not generated in $\mathrm{C} 2 \mathrm{C} 12$ cells treated with $0,0.5$, and $1 \mathrm{mM}$ glyceraldehyde (Fig. $1 \mathrm{~b}$ and Additional file 1: Fig. S1a). Intracellular TAGE dose-dependently increased to 6.0 and $15.9 \mu \mathrm{g} / \mathrm{mg}$ protein in $\mathrm{C} 2 \mathrm{C} 12$ cells treated with 1.5 and $2 \mathrm{mM}$ glyceraldehyde, respectively (Fig. $1 \mathrm{~b}$ and Additional file 1 : Fig. S1a).
Effects of the aminoguanidine pretreatment on the viability of $\mathrm{C} 2 \mathrm{C} 12$ cells treated with glyceraldehyde The viability of $\mathrm{C} 2 \mathrm{C} 12$ cells treated with 1.5 and $2 \mathrm{mM}$ glyceraldehyde without aminoguanidine dose-dependently decreased to 35.0 and $3.0 \%$, respectively (Fig. 1c). In $\mathrm{C} 2 \mathrm{C} 12$ cells pretreated with $8 \mathrm{mM}$ aminoguanidine, cell viabilities were $71.7,71.3$, and $74.3 \%$ in those subsequently treated with $0,1.5$, and $2 \mathrm{mM}$ glyceraldehyde, respectively. No significant differences were observed between each treatment (Fig. 1c). The aminoguanidine pretreatment completely inhibited decreases in the viability of $\mathrm{C} 2 \mathrm{C} 12$ cells treated with 1.5 and $2 \mathrm{mM}$ glyceraldehyde.

\section{Effects of the aminoguanidine pretreatment} on the quantity of intracellular TAGE in $\mathrm{C} 2 \mathrm{C} 12$ cells treated with glyceraldehyde

Glyceraldehyde concentrations of 1.5 and $2 \mathrm{mM}$ without aminoguanidine dose-dependently increased intracellular TAGE to 7.9 and $13.4 \mu \mathrm{g} / \mathrm{mg}$ protein, respectively
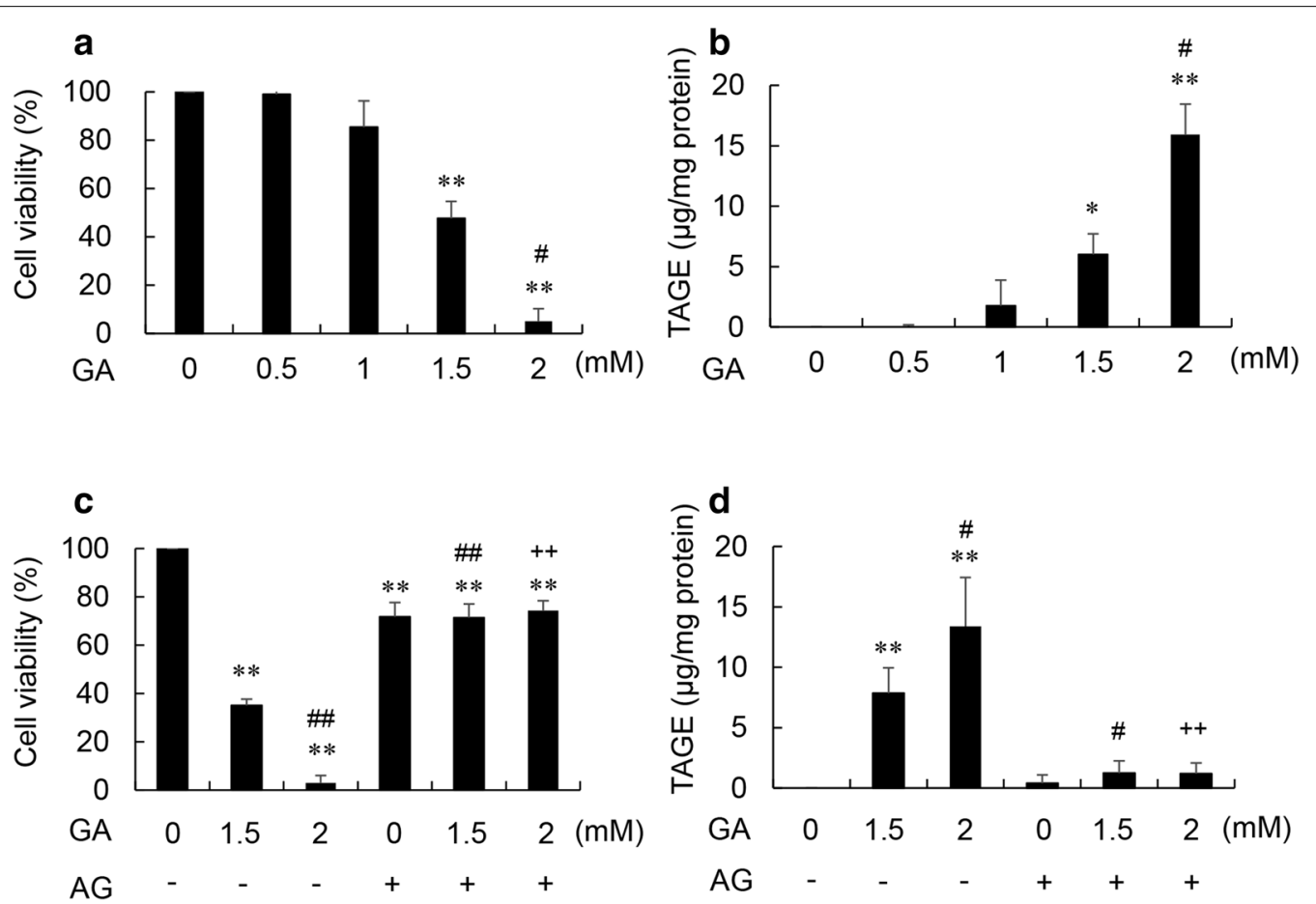

Fig. 1 Cell viability and intracellular TAGE levels in C2C12 cells treated with glyceraldehyde and aminoguanidine. GA: glyceraldehyde. AG: aminoguanidine. $\mathbf{a}$, b Cells were treated with $0,0.5,1,1.5$, and $2 \mathrm{mM} \mathrm{GA}$ for $24 \mathrm{~h}$. c, $\mathbf{d}$ Cells were pretreated with 0 or $8 \mathrm{mM}$ AG for $2 \mathrm{~h}$, followed by $0,1.5$, and $2 \mathrm{mM} \mathrm{GA}$ for $24 \mathrm{~h}$. a, c Cell viability was assessed by the WST-8 assay, which was performed in three independent experiments. One experiment was performed using 7 wells to calculate the average. Data are shown as mean \pm S.D. $(\mathrm{N}=3)$. $\mathbf{b}$, $\mathbf{d}$ Intracellular TAGE were analyzed using a slot blot analysis. Cell lysates ( $2.0 \mu \mathrm{g}$ of protein/lane) were blotted onto a polyvinylidene difluoride membrane. The densities of HRP-linked molecular marker bands were used to correct for differences in densities between membranes. The amount of TAGE was calculated based on a calibration curve for TAGE-BSA. A slot blot analysis was performed in three independent experiments. One experiment was performed using 2 lanes to calculate the average. Data are shown as mean \pm S.D. $(\mathrm{N}=3)$. a, b P-values were based on the Bonferroni test. ${ }^{*} p<0.05$ vs. 0 mM GA. ${ }^{* *} p<0.01$ vs. 0 mM GA. ${ }^{\#} p<0.05$ vs. 1.5 mM GA. c, d P-values were based on Tukey's test. ${ }^{* *} p<0.01$ vs. 0 mM GA without AG. ${ }^{*} p<0.05$ vs. 1.5 mM GA without AG. $\#$ \# $p<0.01$ vs. $1.5 \mathrm{mM}$ GA without $A \mathrm{G} .{ }^{++} p<0.01$ vs $2 \mathrm{mM}$ GA without AG 
(Fig. 1d and Additional file 1: Fig. S1b). Intracellular TAGE levels in C2C12 cells pretreated with $0 \mathrm{mM}$ aminoguanidine followed by $0 \mathrm{mM}$ glyceraldehyde and in those pretreated with $8 \mathrm{mM}$ aminoguanidine followed by $0,1.5$, and $2 \mathrm{mM}$ glyceraldehyde were not significantly different. The aminoguanidine pretreatment completely inhibited the generation of intracellular TAGE in C2C12 cells treated with 1.5 and $2 \mathrm{mM}$ glyceraldehyde (Fig. $1 \mathrm{~d}$ and Additional file 1: Fig. S1b).

\section{Serum TAGE levels in STAM mice}

Serum TAGE levels in the no steatosis and simple steatosis stage groups were $7.27 \pm 0.18$ and $8.69 \pm 1.01 \mathrm{U} /$ $\mathrm{mL}$, respectively (Fig. 2a). Serum TAGE levels in the steatohepatitis and fibrosis stage groups increased to $10.51 \pm 1.16$ and $10.44 \pm 0.95 \mathrm{U} / \mathrm{mL}$, which were higher than that in the no steatosis stage group.

\section{Viability of $C 2 C 12$ cells treated with non-glycated BSA and TAGE-BSA}

No significant differences were observed in the viability of $\mathrm{C} 2 \mathrm{C} 12$ cells treated with 0,20 , and $50 \mu \mathrm{g} / \mathrm{mL}$ of nonglycated BSA and TAGE-BSA (Additional file 2: Fig. S2). The viabilities of $\mathrm{C} 2 \mathrm{C} 12$ cells treated with $100 \mu \mathrm{g} / \mathrm{mL}$ non-glycated BSA and TAGE-BSA were 105.0 and $85.3 \%$, respectively, and the ratio of cell viability was $81.2 \%$ (Fig. 2b).

\section{Discussion}

Glyceraldehyde, which is a precursor of TAGE, is generated in the liver via three pathways $[11,15,23]$. (1) Glucose is metabolized to glyceraldehyde-3-phospate via glycolysis, and glyceraldehyde is produced by its dephosphorization through a non-enzymatic reaction. (2) Fructose is metabolized to glyceraldehyde via the pathway involving fructokinase and aldolase B (fructolysis). (3) Glucose is metabolized to fructose via the sorbitol pathway, which regulates aldose reductase and sorbitol dehydrogenase, and this fructose is metabolized to glyceraldehyde via fructolysis. Since skeletal muscle uses glycolysis and contains fructokinase, aldolase B, aldose reductase, and sorbitol dehydrogenase [26-28], we considered the three pathways of glyceraldehyde metabolism to occur in skeletal muscle, similar to the liver. CML and CEL are produced by some pathways from glucose [11, $15,23]$, and CEL is produced by the degradation of the products of fructoselysine in glycated proteins [29].

CML- and CEL-modified proteins have been suggested to cause sarcopenia in $\mathrm{C} 57 \mathrm{Bl} / 6 \mathrm{j}$ mice fed a high-fat high-sugar diet and a high-fructose diet and also in ob/ ob mice fed a standard diet based on the loss of muscle mass, myosteatosis, and oxidative stress in the gastrocnemius of these animals $[9,10]$. However, the relationships between these AGEs and cell death in myoblasts remain unclear.
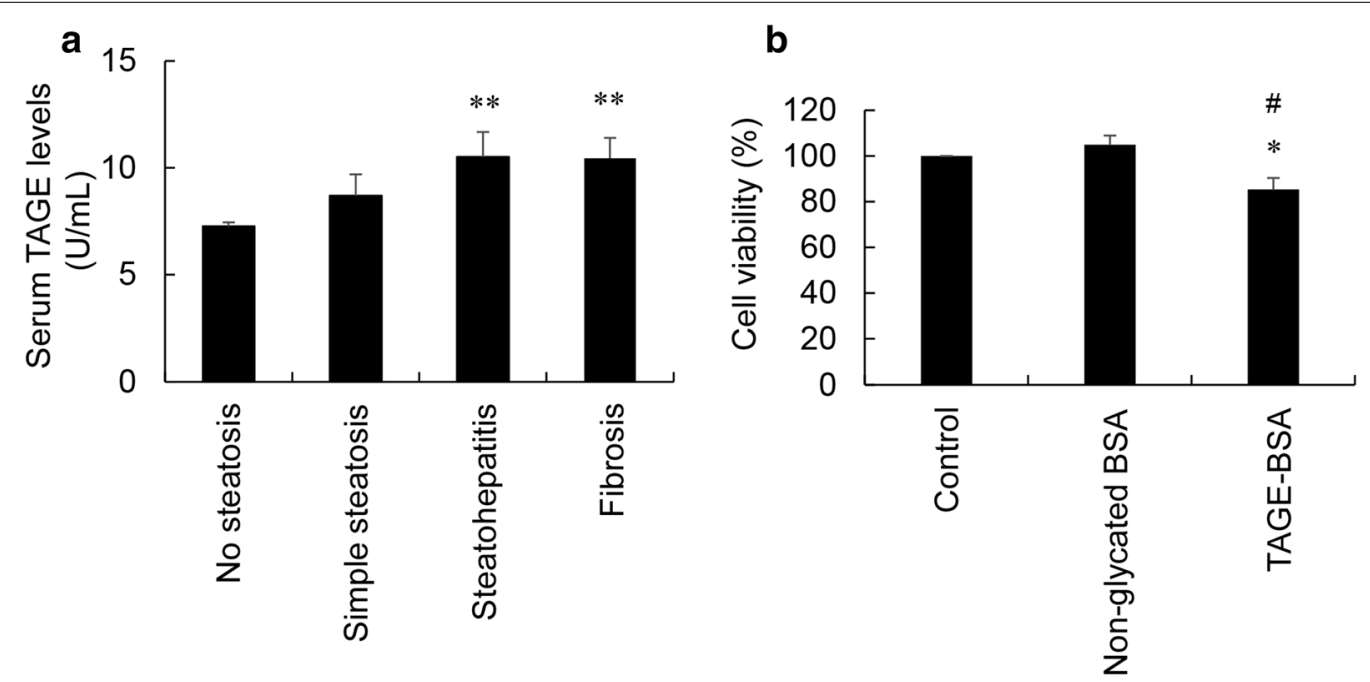

Fig. 2 Serum TAGE levels in STAM mice and cytotoxicity of TAGE-BSA against C2C12 cells. a Serum TAGE levels in the four stage groups of STAM mice were measured using a competitive enzyme-linked immunosorbent assay. Results were expresses as TAGE units $(U) / \mathrm{mL}$ of serum, with $1 \mathrm{U}$ corresponding to $1.0 \mathrm{\mu g}$ of TAGE-BSA. There were 4 mice in each group. One experiment was performed using 4 wells against the serum of one mouse to calculate the average. Data are shown as mean \pm S.D. $(N=4)$. P-values were based on the Bonferroni test. ${ }^{* *} p<0.01$ vs. the no steatosis stage. $\mathbf{b}$ Cells were treated with 0 and $100 \mu \mathrm{g} / \mathrm{mL}$ non-glycated BSA and TAGE-BSA for $24 \mathrm{~h}$. Cell viability was assessed by the WST-8 assay. This assay was performed in three independent experiments. One experiment was performed using 7 wells to calculate the average. Data are shown as mean \pm S.D. $(N=3)$. P-values were based on the Bonferroni test. ${ }^{*} p<0.05$ vs. the control. ${ }^{*} p<0.05$ vs. the non-glycated BSA treatment 
Therefore, we considered it important to investigate AGEs generated in myoblasts in order to clarify whether the mechanisms contributing to the loss of skeletal muscle involve the death of or dysfunctions in myoblasts. Although CML- and CEL-modified proteins may be generated in myoblasts, we hypothesized that TAGE are produced by these cells and induce cytotoxicity based on previous findings showing their production by neuroblastoma cells, hepatic cells, pancreatic cells, and cardiac cells and induction of cell death [16-22].

We treated $\mathrm{C} 2 \mathrm{C} 12$ cells with glyceraldehyde to rapidly generate intracellular TAGE. In the present study, $\mathrm{C} 2 \mathrm{C} 12$ cells were treated with glyceraldehyde at a physiological concentration to generate TAGE within $24 \mathrm{~h}$. Taniguchi et al. [30] previously demonstrated that islets of the pancreas exposed to $20 \mathrm{mM}$ glucose accumulated $0.025 \mathrm{pmol} /$ islet glyceraldehyde, whereas exposure to $10 \mathrm{mM}$ glyceraldehyde caused the accumulation of $0.12 \mathrm{pmol} /$ islet glyceraldehyde. Based on these findings, Takahashi et al. [31] used $2 \mathrm{mM}$ glyceraldehyde in their experiments, which is a similar concentration to $20 \mathrm{mM}$ glucose. On the other hand, plasma levels of glucose in NASH and T2DM model mice increased by more than $25 \mathrm{mM}$ [32-34]. The viability of $\mathrm{C} 2 \mathrm{C} 12$ cells treated with 1.5 and $2 \mathrm{mM}$ glyceraldehyde for $24 \mathrm{~h}$ dose-dependently decreased (Fig. 1a). In contrast, intracellular TAGE were generated in a dose-dependent manner (Fig. 1b and Additional file 1: Fig. S1a). To demonstrate that the generation of TAGE decreased cell viability, $\mathrm{C} 2 \mathrm{C} 12$ cells were pretreated with $8 \mathrm{mM}$ aminoguanidine, an inhibitor of the generation of AGEs, for $2 \mathrm{~h}$ followed by 1.5 and $2 \mathrm{mM}$ glyceraldehyde for $24 \mathrm{~h}$. Aminoguanidine inhibited decreases in cell viability as well as the generation of TAGE (Fig. 1c, d and Additional file 1: Fig. S1b). To the best of our knowledge, this is the first study to show that intracellular TAGE were generated from glyceraldehyde at a physiological concentration in myoblasts and strongly induced cell death. The death of myoblasts will lead to the loss of skeletal muscle. Living myoblasts that generate intracellular TAGE may also ultimately lead to the loss of skeletal muscle. In our previous study, when rat primary cardiomyocytes were treated with $4 \mathrm{mM}$ glyceraldehyde for $6 \mathrm{~h}$, cell viability decreased to $39.2 \%$ and intracellular TAGE were generated at $12.0 \mu \mathrm{g} / \mathrm{mg}$ protein [22]. Furthermore, living cardiomyocytes completely stopped beating. The viability of $\mathrm{C} 2 \mathrm{C} 12$ cells treated with $1.5 \mathrm{mM}$ glyceraldehyde was $47.7 \%$ and living cells generated intracellular TAGE levels of $6.0 \mu \mathrm{g} /$ mg protein (Fig. 1a, b and Additional file 1: Fig. S1a). The generation of skeletal muscle may be inhibited in myotubes with dysfunctional differentiation [2-6]. Collectively, these findings and the present results suggest that the cell death or dysfunction of myoblasts that gain excess glucose or fructose and generate high levels of intracellular TAGE may inhibit the differentiation of myoblasts.

TAGE in the blood which are one of extracellular TAGE increase in patients with LSRD and induce responses such as inflammation and oxidative stress in cells via RAGE [11-13, 15, 23]. Extracellular TAGE which are generated in other cells and secreted or released into the blood may induce cytotoxicity in myoblasts because they express RAGE [2]. Therefore, we investigated the cytotoxicity of TAGE-BSA, a model of extracellular TAGE, in $\mathrm{C} 2 \mathrm{C} 12$ cells. We considered that the concentration of TAGE-BSA should be decided based on the physiological concentration of TAGE in the blood of LSRD model mice. Since we previously reported that serum TAGE levels were higher in NASH patients than in healthy controls and patients with simple steatosis [14], we measured serum TAGE levels in STAM mice, a NASH model. Serum TAGE levels were approximately 1.4-fold higher in the steatohepatitis and fibrosis stages than in the no steatosis stage, and ranged between approximately 7 and $11 \mathrm{U} / \mathrm{mL}$ (Fig. 2a). Although we did not measure serum TAGE levels in other LSRD model mice, we speculate that they may not differ markedly range between 7 and $12 \mathrm{U} / \mathrm{mL}$ based on the data of serum TAGE levels of many patients with LSRD such as NASH, T2DM, and CVD [14, 25, 35, 36]. We applied 20, 50, and $100 \mu \mathrm{g} /$ mL TAGE-BSA, which are approximately 2,5 , and tenfold, respectively, that of serum TAGE levels in STAM mice that develop steatohepatitis and fibrosis (Fig. 2 and Additional file 2: Fig. S2). To examine the effects of TAGE in $\mathrm{C} 2 \mathrm{C} 12$ cells, we assessed the viability of $\mathrm{C} 2 \mathrm{C} 12$ cells treated with non-glycated BSA and TAGE-BSA. Only $100 \mu \mathrm{g} / \mathrm{mL}$ TAGE-BSA slightly decreased cell viability (Fig. 2b). Therefore, extracellular TAGE do not appear to induce cell death under physiological conditions.

\section{Conclusion}

The present study demonstrated that intracellular TAGE were generated in $\mathrm{C} 2 \mathrm{C} 12$ cells and more strongly induced cell death than extracellular TAGE. Therefore, intracellular TAGE may induce cell death in the myoblasts of LSRD model mice.

\section{Supplementary information}

Supplementary information accompanies this paper at https://doi. org/10.1186/s13098-020-00561-z.

Additional file 1: Figure S1. Images of PVDF membranes for the slot blot analysis in Fig. $1 \mathrm{~b}$ and d. (a) An image of PVDF membranes for slot blot analysis on Fig. 1b. The left membrane was incubated with an antiTAGE antibody. The right membrane was incubated with a neutralized anti-TAGE antibody. L1 and 4: TAGE-BSA (0, 1, 3, 10, 30, 60, and $100 \mathrm{ng}$ of protein/lane) and a HRP-linked molecular marker were loaded onto 
the membranes. L2, 3, 5, and 6: Cell lysates ( $2.0 \mu \mathrm{g}$ of protein/lane) of C2C12 cells treated with $0,0.5,1,1.5$, and $2 \mathrm{mM}$ glyceraldehyde for 24 h. (b) An image of PVDF membranes for the slot blot analysis in Fig. 1d. The left membrane was incubated with an anti-TAGE antibody. The right membrane was incubated with a neutralized anti-TAGE antibody. L1 and 4 : TAGE-BSA $(0,1,3,10,30,60$, and $100 \mathrm{ng}$ of protein/lane) and a HRP-linked molecular marker were loaded onto the membranes. L2, 3, 5, and 6: The bands in the open box with a solid line; Cell lysates ( $2.0 \mu \mathrm{g}$ of protein/lane) of $\mathrm{C} 2 \mathrm{C} 12$ cells treated with $0,1.5$, and $2 \mathrm{mM}$ glyceraldehyde without aminoguanidine for $24 \mathrm{~h}$ were loaded onto PVDF membranes. Bands in the open box with a broken line; Cell lysates ( $2.0 \mu \mathrm{g}$ of protein/lane) of $\mathrm{C} 2 \mathrm{C} 12$ cells pretreated with $8 \mathrm{mM}$ aminoguanidine for $2 \mathrm{~h}$, followed by $0,1.5$, and $2 \mathrm{mM}$ glyceraldehyde were loaded onto membranes.

Additional file 2: Figure S2. Cell viability of $\mathrm{C} 2 \mathrm{C} 12$ cells treated with nonglycated BSA and TAGE-BSA. (a) Cells were treated with 0 and $20 \mu \mathrm{g} / \mathrm{mL}$ of non-glycated BSA and TAGE-BSA for $24 \mathrm{~h}$. (b) Cells were treated with 0 and $50 \mu \mathrm{g} / \mathrm{mL}$ of non-glycated BSA and TAGE-BSA for $24 \mathrm{~h}$. (a, b) Cell viability was assessed by the WST- 8 assay. This assay was performed in three independent experiments. One experiment was performed using 7 wells to calculate the average. Data are shown as means \pm S.D. $(N=3)$. P-values were based on the Bonferroni test.

\section{Abbreviations}

LSRD: Lifestyle-related diseases; AGEs: Advanced glycation end-products; TAGE: Toxic advanced glycation end-products; T2DM: Type 2 diabetes mellitus; NASH: Non-alcoholic steatohepatitis; CML: $N^{\varepsilon}$-carboxymethyllysine; CEL: $N^{\varepsilon}$ carboxyethyllysine; CVD: Cardiovascular disease.

\section{Acknowledgements}

Not applicable.

\section{Authors' contributions}

TT and MT designed the research, TT and AS-S performed the research, MT contributed reagents that were indispensable for this investigation, TT and AS-S analyzed data, and TT and MT wrote the manuscript. All authors read and approved the final manuscript.

\section{Funding}

The present study was funded by JSPS KAKENHI (Grant Numbers JP16H01811 \& JP18K11139) and Assist KAKEN from Kanazawa Medical University (K2019-24).

\section{Availability of data and materials}

The datasets used and/or analyzed during the present study are available from the corresponding author upon reasonable request.

\section{Ethics approval and consent to particle}

Not applicable.

\section{Consent for publication}

Not applicable.

\section{Competing interests}

The authors declare that they have no competing interests.

Received: 8 February 2020 Accepted: 17 June 2020

Published online: 29 June 2020

\section{References}

1. Ronden M, Shulman Gl. The integrative biology of type 2 diabetes. Nature. 2019;576(7785):51-60.

2. Adachi N, Kanazawa I, Tanaka K, Takeno A, Notsu M, Tanaka S, et al. Insulinlike growth factor-I protects against the detrimental effects of advanced glycation end products and high glucose in myoblastic C2C12 cell. Calcif Tissue Int. 2019;105(1):89-96.

3. Sato H, Funaki A, Kimura Y, Sumitomo M, Yoshida H, Fukata $H$, et al. Ethanol extract of Cyclolepis genistoides D. Don (palo azul) induces formation of myotubes, which involves differentiation of C2C12 myoblast cells. Nutr Res. 2016;36(7):731-41.

4. Burks TN, Cohn RD. Role of TGF- $\beta$ signaling in inherited and acquired myopathies. Skelet Muscle. 2011;1(1):19.

5. Byun SK, An TH, Son MJ, Lee DS, Kang HS, Lee EW, et al. HDAC11 inhibits myoblast differentiation through repression of MyoD-dependent transcription. Mol Cells. 2017:40(9):667-76.

6. Tanaka K, Kanazawa I, Yamaguchi T, Yano S, Kaji H, Sugimoto T. Active vitamin D possesses beneficial effects on the interaction between muscle and bone. Biochem Biophys Res Commun. 2014;450(1):482-7.

7. Bhanji RA, Narayanan P, Moynagh MR, Takahashi N, Angirekula M, Kennedy CC, et al. Differing impact of sarcopenia and frailty in nonalcoholic steatohepatitis and alcoholic liver disease. Liver Transpl. 2019;25(1):14-24.

8. Petta S, Ciminnisi S, Di Marco V, Cabibi D, Cammà C, Licata A, et al. Sarcopenia is associated with severe liver fibrosis in patients with non-alcoholic fatty liver disease. Aliment Pharmacol Ther. 2017;45(4):510-8.

9. Mastrocola R, Collino M, Nigro D, Chiazza F, D'Antona G, Aragno M, et al. Accumulation of advanced glycation end-products and activation of SCAP/SREBP lipogenetic pathway occur in diet-induced obese mouse skeletal muscle. PLoS ONE. 2015;10(3):e0119587.

10. Mastrocola R, Nigro D, Chiazza F, Medana C, Dal Bello F, Boccuzzi G, et al. Fructose-derived advanced glycation end-products drive lipogenesis and skeletal muscle reprogramming via SREBP-1c dysregulation in mice. Free Radic Biol Med. 2016;91:224-35.

11. Takeuchi M. Serum levels of Toxic AGEs (TAGE) may be a promising novel biomarker for the onset/progression of lifestyle-related diseases. Diagnostics. 2016;6:23.

12. Takeuchi M, Takino J, Sakasai-Sakai A, Takata T, Tsutsumi M. Toxic AGE (TAGE) theory for the pathophysiology of the onset/progression of NAFLD and ALD. Nutrients. 2017;9:634.

13. Sakasai-Sakai $A$, Takata T, Takino J, Takeuchi $M$. The relevance of Toxic AGEs (TAGE) cytotoxicity to NASH pathogenesis: a mini-review. Nutrients. 2019;11:462.

14. Hyogo H, Yamagishi S, Iwamoto K, Arihiro K, Takeuchi M, Sato T, et al. Elevated levels of serum advanced glycation end products in patients with non-alcoholic steatohepatitis. J Gastroenterol Hepatol. 2007;22(7):1112-9.

15. Takino J, Nagamine K, Hori T, Sakasa-Sakai A, Takeuchi M. Contribution of the toxic advanced glycation end-products-receptor axis in nonalcoholic steatohepatitis-related hepatocellular carcinoma. World J Hepatol. 2015;7(23):2459-69.

16. Koriyama Y, Furukawa A, Muramatsu M, Takino J, Takeuchi M. Glyceraldehyde caused Alzheimer's disease-like alterations in diagnostic marker levels in SH-SY5Y human neuroblastoma cells. Sci Rep. 2015;5:13313.

17. Takino J, Kobayashi Y, Takeuchi M. The formation of intracellular glyceraldehyde-derived advanced glycation end-products and cytotoxicity. J Gastroenterol. 2010;45(6):646-55.

18. Takino J, Nagamine K, Takeuchi M, Hori T. In vitro identification of nonalcoholic fatty liver disease-related protein hnRNPM. World J Gastroenterol. 2015;21(6):1784-93.

19. Sakasai-Sakai A, Takata T, Takino J, Takeuchi M. Impact of intracellular glycation end-products on human hepatocyte cell death. Sci Rep. 2017;7(1):14282.

20. Takata T, Sakasai-Sakai A, Takino J, Takeuchi M. Evidence for toxic advanced glycation end-products generated in the normal rat liver. Nutrients. 2019;11:1612.

21. Takata T, Ueda T, Sakasai-Sakai A, Takeuchi M. Generation of glyceraldehyde-derived advanced glycation end-products in pancreatic cancer cells and the potential of tumor promotion. World J Gastroenterol. 2017;23(27):4910-9.

22. Takata T, Sakasai-Sakai A, Ueda T, Takeuchi M. Intracellular toxic advanced glycation end-products in cardiomyocytes may cause cardiovascular disease. Sci Rep. 2019;9(1):2121.

23. Takeuchi M, Takino J, Yamagishi S. Involvement of the toxic AGEs (TAGE)RAGE system in the pathogenesis of diabetic vascular complications: a novel therapeutic strategy. Curr Drug Targets. 2010;11(11):1468-82.

24. Takeuchi M, Makita Z, Bucala R, Suzuki T, Koike T, Kameda Y. Immunological evidence that non-carboxymethyllysine advanced glycation end-products are produced from short chain sugars and dicarbonyl compounds in vivo. Mol Med. 2000;6(2):114-25.

25. Jinno M, Takeuchi M, Watanabe A, Teruya K, Hirohama J, Eguchi N, et al. Advanced glycation end-products accumulation compromises 
embryonic development and achievement of pregnancy by assisted reproductive technology. Hum Reprod. 2011;26(3):604-10.

26. Bais R, James HM, Rofe AM, Conyers RAJ. The purification and properties of human liver ketohexokinase. Biochem J. 1985;230(1):53-60.

27. Vander Jagt DL, Robinson B, Taylor KK, Hunsaker LA. Aldose reductase from human skeletal and heart muscle. J Biol Chem. 1990;265(34):20982-7.

28. Lee FK, Lee AYW, Lin CXF, Chung SS, Chung SK. Cloning, sequencing, and determination of the sites of expression of mouse sorbitol dehydrogenase cDNA. Eur J Biochem. 1995;230(3):1059-65.

29. Ahmed MU, Thorpe SR, Baynes JW. Identification of $N^{\varepsilon}$ carboxymethyllsine as a degradation product of fructoselysine in glycated protein. J Biol Chem. 1986;261 (11):4889-94.

30. Taniguchi S, Okinaka M, Tanigawa K, Miwa I. Difference in mechanism between glycelaldehyde-and glucose-induced insulin secretion from isolated rat pancreatic islets. J Biochem. 2000;127(2):289-95.

31. Takahashi H, Tran POT, LeRoy E, Harmon JS, Tanaka Y, Robertson RP. D-glyceraldehyde cause production of intracellular peroxide in pancreatic islets, oxidative stress, and defective beta cell function via non-mitochondrial pathways. J Biol Chem. 2004:279(36):37316-23.

32. Jojima T, Tomotsune T, lijima T, Akimoto K, Suzuki K, Aso Y. Empagliflozin (an SGLT2 inhibitor), alone or in combination with linagliptin (a DPP-4 inhibitor), prevents steatohepatitis in a novel mouse model of nonalcoholic steatohepatitis and diabetes. Diabetol Metab Syndr. 2016;8:45.
33. Khoshi A, Goodarzi G, Mohammadi R, Arezumand R, Moghbeli M, Najariyan $\mathrm{M}$. Reducing effect of insulin resistance on alpha-synuclein gene expression in skeletal muscle. Diabetol Metab Syndr. 2019;11:99.

34. Glastras SJ, Chen H, Teh R, McGrath RT, Chen J, Pollock CA, et al. Mouse model of diabetes, obesity and related kidney disease. PLOS ONE. 2016;11(8):e0162131.

35. Tsunosue M, Mashiko N, Ohta Y, Matsuo Y, Ueda K, Ninomiya M, et al. An a-glucosidase inhibitor, acarbose treatment decreases serum levels of glyceraldehyde-derived advanced glycation end products (AGES) in patients with type 2 diabetes. Clin Exp Med. 2010;10(2):139-41.

36. Fukushima Y, Daida H, Morimoto T, Kasai T, Miyauchi K, Yamagishi S, et al. Relationship between advanced glycation end products and plaque progression in patients with acute coronary syndrome: the JAPAN-ACS sub-study. Cardiovasc Diabetol. 2013;12:5.

\section{Publisher's Note}

Springer Nature remains neutral with regard to jurisdictional claims in published maps and institutional affiliations.
Ready to submit your research? Choose BMC and benefit from:

- fast, convenient online submission

- thorough peer review by experienced researchers in your field

- rapid publication on acceptance

- support for research data, including large and complex data types

- gold Open Access which fosters wider collaboration and increased citations

- maximum visibility for your research: over $100 \mathrm{M}$ website views per year

At BMC, research is always in progress.

Learn more biomedcentral.com/submissions 